\title{
Cytotoxic Sorbicillinoids and Bisorbicillinoids from a Marine-Derived Fungus Trichoderma sp.
}

\author{
Lin Du, Tianjiao Zhu, LiYuan Li, Shengxin CaI, Boyu ZhaO, and Qianqun Gu* \\ Key Laboratory of Marine Drugs, Chinese Ministry of Education, School of Medicine and Pharmacy, Ocean University of \\ China; Qingdao 266003, China. \\ Received October 28, 2008; accepted November 25, 2008; published online November 27, 2008
}

Four sorbicillinoids $(1-4)$ and seven bisorbicillinoids $(5-11)$, including two new compounds, 6-demethylsorbicillin (1) and 10,11-dihydrobisvertinolone (6), were isolated from a marine-derived fungus Trichoderma sp. Their cytotoxic activities against HL-60 cell line were evaluated by Sulforhodamine B (SRB) assay method and flow cytometric analysis.

Key words Trichoderma sp.; sorbicillinoid; bisorbicillinoid

The "sorbicillinoids" and "bisorbicillinoids"1) are defined to designate a group of more than $30^{2)}$ monomeric and dimeric sorbicillin ${ }^{3,4)}$-related natural products, which are produced by a few fungal genera (Trichoderma, Verticillium, and Penicillium) ${ }^{5)}$ The dimers form two groups: the Diels-Alder products such as bisorbicillinol (9) and the Michael-type adducts which are at least tricyclic as in bisvertinolone (5). ${ }^{2)}$ All monomers and dimers exhibit a pronounced radical-scavenging activity, ${ }^{6,7)}$ and some bisorbicillinoids show promising biological properties such as cytotoxicity, ${ }^{8,9)}$ inhibition of the biosynthesis of $\beta$-1,6-glucan ${ }^{10)}$ and the production of tumor necrosis factor $\alpha(\mathrm{TNF}-\alpha)^{11)}$ induced by lipopolysaccharide. Isobisvertinol, a new stereoisomer of bisvertinol, shows unique activity to inhibit lipid droplet accumulation in macrophages. ${ }^{12)}$

In our search for antitumor compounds from marinederived microorganisms, a fungus, authenticated as Trichoderma sp., was obtained from the marine sediment collected in Fujian province of China. The isolation work of the active compounds on this fungus led to the finding of two new compounds $(\mathbf{1}, \mathbf{6})$, along with nine known compounds [sohirnones A (2), sorbicillin (3), 2', 3'-dihydrosorbicillin (4), bisvertinolone (5), trichodimerol (7), dihydrotrichodimerol (8), bisorbicillinol (9), bisvertinoquinol (10), bisorbibutenolide (11a)]. ${ }^{2,8,10,13-15)}$ The known compounds were identified by comparisons with previously reported physical and spectral data. In this paper, we describe the isolation, structure elucidation of two new compounds, and cytotoxic activities against HL-60 cell line of all compounds.

Compound 1 was obtained as a yellow powder. Its molecular formula $\mathrm{C}_{13} \mathrm{H}_{14} \mathrm{O}_{3}$ was determined by HR-electron spray ionization (ESI)-MS $\left(m / z 219.1017[\mathrm{M}+\mathrm{H}]^{+}\right.$, Calcd 219.1021), indicating seven degrees of unsaturation. Comparison of the ${ }^{1} \mathrm{H}$ - and ${ }^{13} \mathrm{C}-\mathrm{NMR}$ data (Table 1) with those of the known compounds sohirnones A (2), ${ }^{2)}$ sorbicillin (3) ${ }^{13)}$ and $2^{\prime}, 3^{\prime}$-dihydrosorbicillin $(4)^{2)}$ indicated that they had the same skeleton. Further comparison of the 1D NMR spectra of $\mathbf{1}$ with those of $\mathbf{3}$ suggested that $\mathbf{1}$ possessed a sorbyl group $\left(\delta_{\mathrm{H}} 7.46, \mathrm{H}-9 ; 6.35, \mathrm{H}-10 ; 6.30, \mathrm{H}-11 ; 1.91, \mathrm{H}-12 ; \delta_{\mathrm{C}}\right.$ 192.9, C-7; 122.3, C-8; 145.4, C-9; 131.1, C-10; 142.0, C$11 ; 19.5, \mathrm{C}-12$ ) as 3 , but one of the aromatic methyl groups of $\mathbf{3}$ was missing in $\mathbf{1}$. An additional aromatic proton signal appeared at $\delta 6.36$ and the very small coupling between the two aromatic protons pointed to their para orientation as in
2. The structure of $\mathbf{1}$ was finally confirmed, named 6demethylsorbicillin. The trans configuration of the double bond was shown by the same pattern of the proton signals and nearly identical ${ }^{1} \mathrm{H}$ and ${ }^{13} \mathrm{C}$ shifts for the side chain as in 3.

Compound 6 was obtained as a yellow powder and it was analyzed by HR-ESI-MS $\left(\mathrm{m} / \mathrm{z} 515.2265[\mathrm{M}+\mathrm{H}]^{+}\right.$, Calcd 515.2281) for the molecular formula $\mathrm{C}_{28} \mathrm{H}_{34} \mathrm{O}_{9}$. Its IR spectrum exhibited strong absorptions at 3420 and $1670 \mathrm{~cm}^{-1}$, indicative of hydroxy and conjugated carbonyl groups. Analysis of the ${ }^{13} \mathrm{C}$-NMR data for $\mathbf{6}$ revealed 13 quaternary carbons, 7 methines, 2 methylenes and 6 methyls. The ${ }^{1} \mathrm{H}$ - and ${ }^{13} \mathrm{C}$-NMR data (Table 1) were very similar to those of bisvertinolone (5) ${ }^{10)}$ and it indicated that they had the same constitution except that one double bond on one of the two side chains in $\mathbf{5}$ was hydrogenated in $\mathbf{6}$. The chemical shifts of C-15-C-20 ( $\delta 186.2,122.4,149.0,131.9,144.8,19.2)$ were consistent with those in $\mathbf{5}$, indicating that the hydrogenation occurred on the other side chain. The doublet peak shapes of $\mathrm{CH}_{3}-14$ in ${ }^{1} \mathrm{H}-\mathrm{NMR}$ spectrum indicted that the C$12 / \mathrm{C}-13$ double bond should not be hydrogenated. Further comparison of the ${ }^{13} \mathrm{C}-\mathrm{NMR}$ data of C-9-C-14 ( $\delta$ 181.0, $33.5,30.3,129.9,127.1,18.5)$ with those of the $10,11,16,17$ hydrogenated analog tetrahydrobisvertinolone ${ }^{9)}$ could definitely help to determine that the C-10/C-11 double bond was hydrogenated. So the structure of $\mathbf{6}$ was established as the 10,11-hydrogeneted analog of 5, named 10,11-dihydrobisvertinolone. The biosynthesis and the absolute configuration of bisvertinolone (5) produced by Trichoderma sp. have been well confirmed by a biosynthetic method using oxosorbicillinol and sorbicillinol as the direct precursors. ${ }^{16)}$ The absolute configurations of dihydrobisvertinolone and tetrahydrobisvertinolone were consistent with that of bisvertinolone (5) by comparison of their nuclear Overhauser effect spectroscopy (NOESY) and circular dichroism (CD) spectra. ${ }^{9)}$ So the absolute configuration of $\mathbf{6}$ was determined to be the same as $\mathbf{5}$ on biogenetic ground and by their similar ${ }^{1} \mathrm{H}$ and ${ }^{13} \mathrm{C}$ shifts and specific rotations $\left(-340^{\circ}\right.$ for $\mathbf{6},-495^{\circ}$ for $\mathbf{5}$, lit. ${ }^{10)}$ ).

The cytotoxic effects of compounds $\mathbf{1}-\mathbf{1 1}$ were preliminarily evaluated against HL-60 cell line using VP16 as positive control. As shown in Table 2, compounds 5 and 7 displayed relatively more potent cytotoxic activities compared with the other compounds. Notably, both monomers and 
Table 1. ${ }^{1} \mathrm{H}-(600 \mathrm{MHz})$ and ${ }^{13} \mathrm{C}-(150 \mathrm{MHz})$ NMR Data for Compounds $\mathbf{1}$ and $\mathbf{6}$ in $\mathrm{CDCl}_{3}$

\begin{tabular}{|c|c|c|c|c|}
\hline \multirow{2}{*}{ No. } & \multicolumn{2}{|r|}{1} & \multicolumn{2}{|c|}{6} \\
\hline & $\delta_{\mathrm{C}}$ & $\delta_{\mathrm{H}}$ & $\delta_{\mathrm{C}}$ & $\delta_{\mathrm{H}}$ \\
\hline 1 & 165.2 & & 99.6 & \\
\hline 1a & & & 55.5 & $3.67(1 \mathrm{H}, \mathrm{s})$ \\
\hline 2 & 114.8 & & 191.1 & \\
\hline 3 & 132.5 & $7.55(1 \mathrm{H}, \mathrm{s})$ & 110.7 & \\
\hline 4 & 116.3 & & 164.2 & \\
\hline $4 \mathrm{a}$ & & & 80.5 & \\
\hline $5 \mathrm{a}$ & & & 104.6 & \\
\hline 5 & 161.5 & & 79.6 & \\
\hline 6 & 103.8 & $6.36(1 \mathrm{H}, \mathrm{s})$ & 197.1 & \\
\hline 7 & 192.9 & & 107.7 & \\
\hline 8 & 122.3 & $6.93(1 \mathrm{H}, \mathrm{d}, 14.6)$ & 200.5 & \\
\hline $8 \mathrm{a}$ & & & 60.1 & \\
\hline 9 & 145.4 & $7.46(1 \mathrm{H}, \mathrm{dd}, 14.6,10.5)$ & 181.0 & \\
\hline 10 & 131.1 & $6.35(1 \mathrm{H}, \mathrm{m})$ & 33.5 & $2.49(1 \mathrm{H}, \mathrm{m}), 2.64(1 \mathrm{H}, \mathrm{m})$ \\
\hline 11 & 142.0 & $6.30(1 \mathrm{H}, \mathrm{m})$ & 30.3 & $2.40(1 \mathrm{H}, \mathrm{m})$ \\
\hline 12 & 19.5 & $1.91(3 \mathrm{H}, \mathrm{d}, 6.4)$ & 129.9 & $5.50(1 \mathrm{H}, \mathrm{m})$ \\
\hline 13 & & & 127.1 & $5.50(1 \mathrm{H}, \mathrm{m})$ \\
\hline 14 & & & 18.5 & $1.63(3 \mathrm{H}, \mathrm{d}, 5.5)$ \\
\hline 15 & & & 186.2 & \\
\hline 16 & & & 122.4 & $7.40(1 \mathrm{H}, \mathrm{d}, 14.8)$ \\
\hline 17 & & & 149.0 & $7.59(1 \mathrm{H}, \mathrm{dd}, 14.8,9.9)$ \\
\hline 18 & & & 131.9 & $6.35(1 \mathrm{H}, \mathrm{m})$ \\
\hline 19 & & & 144.8 & $6.35(1 \mathrm{H}, \mathrm{m})$ \\
\hline 20 & & & 19.2 & $1.92(3 \mathrm{H}, \mathrm{d}, 4.9)$ \\
\hline $\mathrm{CH}_{3}-3$ & & & 7.5 & $1.51(3 \mathrm{H}, \mathrm{s})$ \\
\hline $\mathrm{CH}_{3}-4$ & 15.8 & $2.20(3 \mathrm{H}, \mathrm{s})$ & & \\
\hline $\mathrm{CH}_{3}-4 \mathrm{a}$ & & & 25.9 & $1.49(3 \mathrm{H}, \mathrm{s})$ \\
\hline $\mathrm{CH}_{3}-5$ & & & 23.6 & $1.40(3 \mathrm{H}, \mathrm{s})$ \\
\hline $\mathrm{CH}_{3}-8 \mathrm{a}$ & & & 19.8 & $1.44(3 \mathrm{H}, \mathrm{s})$ \\
\hline $\mathrm{OH}-1$ & & $13.27(1 \mathrm{H}, \mathrm{s})$ & & \\
\hline OH-9 & & & & $17.75(1 \mathrm{H}, \mathrm{s})$ \\
\hline $\mathrm{OH}-15$ & & & & $16.66(1 \mathrm{H}, \mathrm{s})$ \\
\hline
\end{tabular}<smiles>CC=CC=CC(=O)c1cc(O)ccc1I</smiles><smiles>C/C=C/CC(=O)c1cc(O)c(O)cc1O</smiles><smiles>C/C=C/C=C/C(=O)c1cc(C)c(O)c(C)c1O</smiles><smiles>C/C=C/CCC(=O)c1cc(C)c(O)c(C)c1O</smiles>

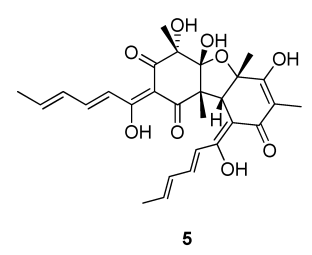

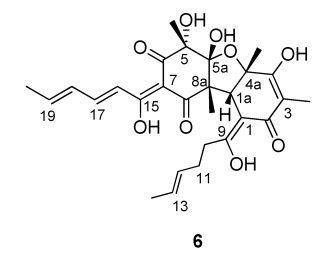

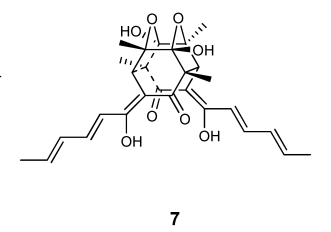

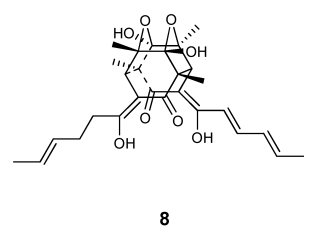

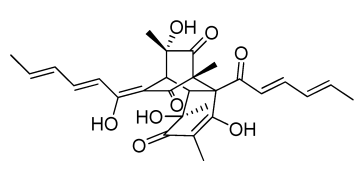

9

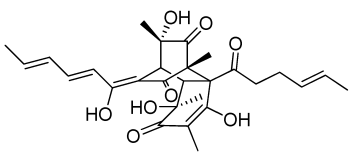

10

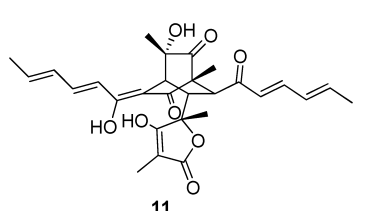

11

Fig. 1. Structures of Compounds $\mathbf{1}-\mathbf{1 1}$

dimers with full-unsaturated side chains all showed higher cytotoxity than the corresponding dihydro analogs. Comparison of the percentage of cells with the hypodiploid DNA content determined by flow cytometry (Table 2, Fig. 2) also supported the deduction, suggesting that the conjugated double bonds in side chain might favor the cytotoxic activity of both sorbicillinoids and bisorbicillinoids. Exceptionally, the Diels-Alder products 9-11 all exhibited scarcely any activ- ity at $50 \mu \mathrm{M}$, probably due to the noneffective molecular architecture. Detailed studies on their antitumor activities and related mechanisms of action are being undertaken.

\section{Experimental}

General Experimental Procedures Specific rotations were obtained on a JASCO P-1020 digital polarimeter. UV spectra were recorded on Beckman $\mathrm{DU}^{\circledR} 640$ spectrophotometer. IR spectra were taken on a NICOLET NEXUS 470 spectrophotometer in $\mathrm{KBr}$ discs. ${ }^{1} \mathrm{H}-,{ }^{13} \mathrm{C}-\mathrm{NMR}$ and distortionless en- 

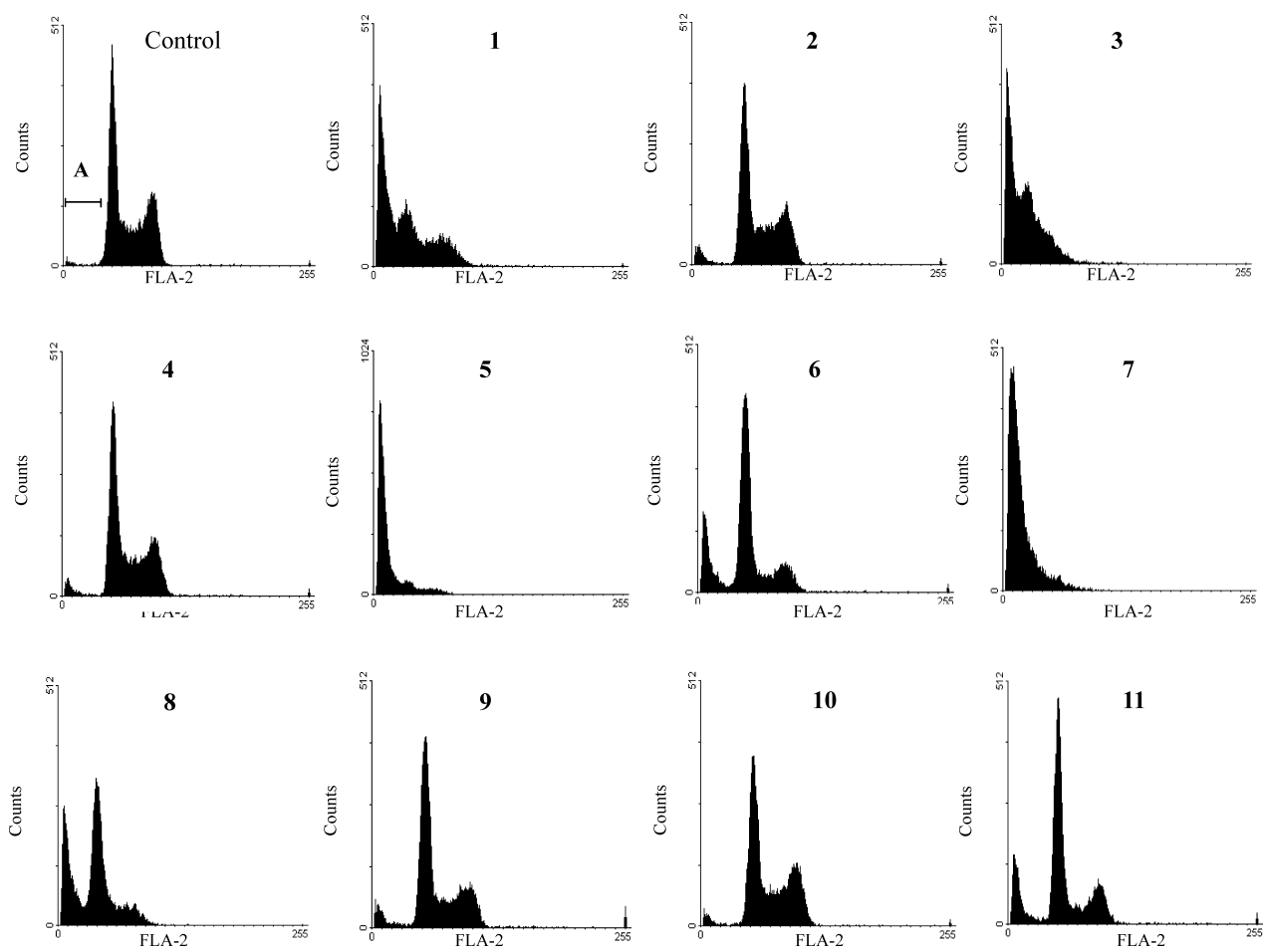

Fig. 2. Determination of Sub- $\mathrm{G}_{1}$ Fractions by Flow Cytometric Analysis

Table 2. Cytotoxic Activity of $\mathbf{1}-\mathbf{1 1}$ against HL-60 Cell Line

\begin{tabular}{lcc}
\hline \hline Compd. & $\mathrm{HL}-60\left(\mathrm{IC}_{50}, \mu \mathrm{M}\right)^{a)}$ & $\mathrm{Sub}^{a}-\mathrm{G}_{1}(\%)^{b)}$ \\
\hline $\mathbf{1}$ & 23.9 & 66.4 \\
$\mathbf{2}$ & $>50$ & 5.4 \\
$\mathbf{3}$ & 12.7 & 79.9 \\
$\mathbf{4}$ & $>50$ & 4.5 \\
$\mathbf{5}$ & 5.3 & 89.6 \\
$\mathbf{6}$ & 49.0 & 22.6 \\
$\mathbf{7}$ & 7.8 & 89.3 \\
$\mathbf{8}$ & 36.4 & 55.7 \\
$\mathbf{9}$ & $>50$ & 7.3 \\
$\mathbf{1 0}$ & $>50$ & 4.0 \\
$\mathbf{1 1}$ & $>50$ & 8.0 \\
Positive control (VP 16) & 2.1 & \\
Negative control (MeOH) & & 2.3 \\
\hline
\end{tabular}

a) $\mathrm{IC}_{50}$ is defined as the concentration that results in a $50 \%$ decrease of viable cell numbers. Data represent mean values of three independent experiments and were determined by the SRB method. b) Data were obtained from histograms. The percentage of sub- $\mathrm{G}_{1}$ fractions was analyzed using the CellQuest computer software.

hancement by polarization transfer (DEPT) spectra and 2D-NMR were recorded on a JEOL JNM-ECP 600 spectrometer using TMS as internal standard and chemical shifts were recorded as $\delta$ values. ESI-MS was measured on a Q-TOF ULTIMA GLOBAL GAA076 LC mass spectrometer. Semipreparative HPLC was performed using an ODS column [YMC-pak ODS-A, $10 \times 250 \mathrm{~mm}, 5 \mu \mathrm{m}, 4 \mathrm{ml} / \mathrm{min}]$.

Fungal Material The fungus, strain f-13, was obtained from the marine sediment collected in Fujian province of China. It was identified as Trichoderma sp. on the basis of its ribosomal internal transcribed spacers and the 5.8S ribosomal RNA gene (ITS1-5.8S-ITS2). Working stocks were prepared on Potato Dextrose agar slants stored at $4{ }^{\circ} \mathrm{C}$ in our labortary.

Fermentation, Extraction, and Isolation Spores were directly inoculated into $500 \mathrm{ml}$ Erlenmeyer flasks containing $200 \mathrm{ml}$ fermentation media (mannitol $20 \mathrm{~g}$, maltose $20 \mathrm{~g}$, glucose $10 \mathrm{~g}$, monosodium glutamate $10 \mathrm{~g}$, $\mathrm{KH}_{2} \mathrm{PO}_{4} 0.5 \mathrm{~g}, \mathrm{MgSO}_{4} \cdot 7 \mathrm{H}_{2} \mathrm{O} 0.3 \mathrm{~g}$, yeast extract $3 \mathrm{~g}$ and corn steep liquor $1 \mathrm{~g}$, dissolved in 11 seawater, $\mathrm{pH} 6.5$ ). The flasks were incubated on a rotatory shaker at $165 \mathrm{rev} . / \mathrm{min}$ at $28^{\circ} \mathrm{C}$. After $12 \mathrm{~d}$ of cultivation, 801 of whole broth was filtered through cheesecloth to separate the broth supernatant and mycelia. The former was extracted with EtOAc while the latter was extracted with acetone. The acetone extract was evaporated under reduced pressure to afford an aqueous solution, and then extracted with EtOAc. The two EtOAc extracts were combined and concentrated in vacuo to give a crude gum $(90 \mathrm{~g})$.

The crude gum $(90 \mathrm{~g})$ was subjected to silica gel column chromatography (petroleum ether-acetone, $\mathrm{v} / \mathrm{v}$, gradient) and the active fractions 2 and 3 eluted with the solvent of petroleum ether-acetone $(8: 2$ and $7: 3)$ were separately subjected to repeating Sephadex LH-20 column chromatography (chloroform-methanol, 1:1). The active subfraction 2-7 was recrystallized to give compounds 7 ( $450 \mathrm{mg}$ ). The other active subfractions 2-2, 3-4-3, and 3-5-7 were further purified respectively by HPLC using a reversed-phase $\mathrm{C}_{18}$ column $\left(70 / 30 \mathrm{MeOH} / \mathrm{H}_{2} \mathrm{O}, 80 / 20 \mathrm{MeOH} / 3 \%\right.$ THF, and 70/30 $\mathrm{CH}_{3} \mathrm{OH} / 0.3 \%$ THF, $4.0 \mathrm{ml} / \mathrm{min})$, to give compounds $1(3.4 \mathrm{mg}), 2(6.5 \mathrm{mg}), 3(33.5 \mathrm{mg})$ and $4(5.3 \mathrm{mg}) ; \mathbf{5}(135.4 \mathrm{mg}), \mathbf{6}(6.5 \mathrm{mg}), \mathbf{8}(25.5 \mathrm{mg})$ and $\mathbf{1 0}(15.3 \mathrm{mg}) ; \mathbf{9}$ $(93.2 \mathrm{mg})$ and $\mathbf{1 1}(84.1 \mathrm{mg})$.

6-Demethylsorbicillin (1): Yellow solid (methanol), IR ( $\mathrm{KBr}) \mathrm{cm}^{-1}: 3419$, 2916, 1640, 1625, 1558, 1485, 1427, 1385, 1362, 1285, 1235, 1180, 1154, 1093, 1072, UV $\lambda_{\max }(\mathrm{MeOH}) \mathrm{nm}(\log \varepsilon): 307$ (4.10), 207 (4.08), ${ }^{1} \mathrm{H}-\mathrm{NMR}$ $\left(\mathrm{CDCl}_{3}, 600 \mathrm{MHz}\right)$ and ${ }^{13} \mathrm{C}-\mathrm{NMR}\left(\mathrm{CDCl}_{3}, 150 \mathrm{MHz}\right)$, see Table 1, HR-ESIMS $m / z: 219.1017[\mathrm{M}+\mathrm{H}]^{+}$(Calcd for $\left.\mathrm{C}_{13} \mathrm{H}_{15} \mathrm{O}_{3}: 219.1021\right)$

10,11-Dihydrobisvertinolone (6): Yellow solid (methanol), $[\alpha]_{\mathrm{D}}^{20}-340^{\circ}$ $(c=0.32, \mathrm{MeOH})$, IR $(\mathrm{KBr}) \mathrm{cm}^{-1}: 3420,2935,1670,1601,1547,1448$, $1379,1345,1212,1100,1154,1026$, UV $\lambda_{\max }(\mathrm{MeOH}) \mathrm{nm}(\log \varepsilon): 358$ (4.17), 307 (sh, 4.07), 229 (4.06), 207 (4.04), ${ }^{1} \mathrm{H}-\mathrm{NMR}\left(\mathrm{CDCl}_{3}, 600 \mathrm{MHz}\right)$ and ${ }^{13} \mathrm{C}-\mathrm{NMR}\left(\mathrm{CDCl}_{3}, 150 \mathrm{MHz}\right)$, see Table 1, HR-ESI-MS $\mathrm{m} / \mathrm{z}: 515.2265$ $[\mathrm{M}+\mathrm{H}]^{+}$(Calcd for $\mathrm{C}_{28} \mathrm{H}_{35} \mathrm{O}_{9}: 515.2281$ ).

In Vitro Cytotoxicity Assays In the Sulforhodamine B (SRB) assay, ${ }^{17)}$ cell suspensions $(200 \mu \mathrm{l})$ were plated in 96-well plates at a density of $2 \times 10^{5}$ cells $/ \mathrm{ml}$. Then the test compound solutions $(2 \mu \mathrm{l}$ in $\mathrm{MeOH})$ at different concentrations were added to each well and further incubated for $24 \mathrm{~h}$. Following drug exposure, the cells were fixed with $12 \%$ trichloroacetic acid and the cell layer was stained with $0.4 \%$ SRB. The absorbance of SRB solution was measured at $515 \mathrm{~nm}$. Dose-response curves were generated and the $\mathrm{IC}_{50}$ values were calculated from the linear portion of log dose-response curves.

In the flow cytometric analysis ${ }^{18)}$ cells were plated in 24-well cell culture plates $\left(2 \times 10^{5}\right.$ cells/well), in triplicate, and then treated with $\mathrm{MeOH}$ (Control) or the compounds $(1-11)$ for $24 \mathrm{~h}$ at the concentration of $50 \mu \mathrm{M}$. Cells were harvested, washed twice with PBS, and the cellular DNA stained with $200 \mu \mathrm{l}$ propidium iodide (PI, $50 \mu \mathrm{g} / \mathrm{ml}$, RNase $1 \mu \mathrm{g} / \mathrm{ml}$, Triton X-100 $0.1 \%$ ). After incubation at $4{ }^{\circ} \mathrm{C}$ for $20 \mathrm{~min}$, the cells were analyzed using flow cytometry (Becton-Dickinson, Vantage, San Diego, CA, U.S.A.). 
Acknowledgments This work was financially supported by the Chinese National Natural Science Fund (No. 30772640), and the Shandong Province (No. Z2006C13)

\section{References}

1) Nicolaou K. C., Jautelat R., Vassilikogiannakis G., Baran P. S., Simonsen K. B., Chem. Eur. J., 5, 3651-3665 (1999).

2) Maskey R. P., Grün-Wollny I., Laatsch H., J. Nat. Prod., 68, 865-870 (2005)

3) Cram D. J., Tishler M., J. Am. Chem. Soc., 70, 4238-4239 (1948).

4) Cram D. J., J. Am. Chem. Soc., 70, 4240-4243 (1948).

5) Abe N., Sugimoto O., Tanji K., Hirota A., J. Am. Chem. Soc., 122, $12606-12607$ (2000).

6) Abe N., Sugimoto O., Arakawa T., Tanji K. I., Hirota A. Biosci. Biotechnol. Biochem., 65, 2271-2279 (2001).

7) Abe N., Arakawa T., Yamamoto K., Hirota A., Biosci. Biotechnol. Biochem., 66, 2090-2099 (2002).

8) Liu W. Z., Gu Q. Q., Zhu W. M., Cui C. B., Fan G. T., J. Antibiot., 58, $621-624$ (2005).

9) Liu W. Z., Gu Q. Q., Zhu W. M., Cui C. B., Fan G. T., J. Antibiot., 58 , $441-446(2005)$
10) Kontani M., Sakagami Y., Marumo S., Tetrahedron Lett., 35, $2577-$ 2580 (1994).

11) Warr G. A., Veitch J. A., Walsh A. W., Hesler G. A., Pirnik D. M., Leet J. E., Lin P. M., Medina I. A., Mcbrien K. D., Forenza S., Clark J. M., Lam K. S., J. Antibiot., 49, 234-240 (1996).

12) Koyama N., Ohshiro T., Tomoda H., Ohmura S., Org. Lett., 9, 425428 (2007).

13) Andradew R., Ayer I. A., Mebe P. P., Can. J. Chem., 70, 2526-2535 (1992).

14) Abe N., Murata T., Hirota A., Biosci. Biotechnol. Biochem., 62, 661666 (1998).

15) Trifonov L. S., Hilpert H., Floersheim P., Dreiding A. S., Rast D. M., Skrivanova R., Hoesch L., Tetrahedron, 42, 3157-3179 (1986).

16) Abe N., Arakawa T., Hirota A., Chem. Commun., 2002, 204-205 (2002).

17) Skehan P., Storeng R., Scudiero D., Monks A., McMahon J., Vistica D., Warren J. T., Bokesch H., Kenney S., Boyd M. R., J. Natl. Cancer Inst., 82, 1107-1112 (1990).

18) Liu R., Zhu T. J., Li D. H., Gu J. Y., Xia Q., Fang Y. C., Liu H. B., Zhu W. M, Gu Q. Q., Arch. Pharm. Res., 30, 270-274 (2007). 